RGSA - Revista de Gestão Social e Ambiental

Jan. - Abr. 2010, V.4, No.1, p. 18-34 ${ }^{1}$

www.gestaosocioambiental.net

\title{
STAKEHOLDERS, NETWORKS AND CONVENTION THEORY IN THE COORDINATION OF PROBLEMS THAT RESULT FROM CLIMATE CHANGES IN AGRIBUSINESS
}

\author{
Denise Barros de Azevedo \\ Doctoral Candidate - Post Graduate Program Center for Research and Studies in Agribusiness \\ (PPGA/CEPAN) at the Federal University of Rio Grande do Sul (UFRGS) Porto Alegre - RS. CNPQ \\ Bursary. Group Studies in Organizations Member (GESTOR). E-mail: deniazevedo@hotmail.com
}

\section{Eugênio Ávila Pedrozo}

Director of Post Graduate Program Center for Research and Studies in Agribusiness (PPGA/CEPAN) and Professor of Post Graduate Program, School of Management (PPGA/EA) at the Federal University of Rio Grande do Sul (UFRGS) Porto Alegre - RS. Coordinator of Group Studies in Organizations (GESTOR).E-mail: eapedrozo@ea.ufrgs.br

\begin{abstract}
Anthropogenic actions have caused an increase of global warming, one of the main environmental problems of the century, challenging humanity and science to find technological alternatives. The insertion of different stakeholders - related to the effects of climate change and its social-economical and environmental unfolding in agribusiness - is necessary, considering the interfaces in different areas of knowledge of new mechanisms that provide common alternatives. This paper consists of a theoretical review of Stakeholder Theory, Networks and Convention Theory. Interactions between these three approaches are possible and also allow the identification of the conventions in face of the formation of networks originated from the dialogues. The framework proposed, called "Insertion Mechanisms of Agribusiness Stakeholders for Climate Change" seeks to analyze how, in the light of the problems arising from climate changes, the insertion process of stakeholders in the agribusiness environment allows a view of the real situation. And, the role of networks and conventions can contribute towards achieving equilibrium when tracing a picture of the behavior among individuals with specific natures in order to generate alternatives for the mitigation of climate change as well as opportunities for agribusiness. As a result, the proposed framework offers a dynamic and active space to study how the forms of coordination occur among the agribusiness stakeholders. The proposed framework offers a dynamic and active space to study how the forms of coordination occur among the agribusiness stakeholders and how the effects of climate change generate forms of opportunities and integration.
\end{abstract}

Keywords: Stakeholders Dialogues, Networks, Convention Theory, Agribusiness.

\section{Resumo}

As ações antropogênicas têm provocado aumento do aquecimento global, um dos principais problemas ambientais do século, desafiando a humanidade e a ciência a encontrar alternativas

\footnotetext{
${ }^{1}$ Recebido em 25.01.2010. Aprovado em 25.03.2010. Disponibilizado em 28.04.2010. Avaliado pelo sistema double blind review
} 
tecnológicas e a buscar outros estilos de produção, consumo e convivência. A inserção de diferentes stakeholders - relacionados aos efeitos das mudanças climáticas e seus desdobramentos sócio-econômicos e ambientais do agronegócio - é necessária, dadas as interfaces de diversas áreas dos conhecimentos em novos mecanismos que proporcionam alternativas comuns. Este trabalho propõe-se a estudar as ações dos diálogos com stakeholders do agronegócio relacionadas aos efeitos das mudanças climáticas; e propor um framework inserindo as abordagens de Teoria de Stakeholders, de Redes e da Teoria das Convenções para conhecer as convenções que estão nas ações. Como resultado, verificou-se que os diálogos entre diferentes stakeholders identificaram seis justificativas que permitem as convenções (inspiração, doméstica, opinião, cívica, mercantil e industrial) que condicionam a reconhecer cada ação gerada nos cinco estudos de casos apresentados. O framework proposto oferece um espaço ativo e dinâmico para estudar como incidem as formas de coordenações entre os stakeholders dos agronegócios e como os efeitos das mudanças climáticas proporcionam formas de integração e oportunidades.

Palavras-chave: Diálogos entre Stakeholders, Redes, Teoria das Convenções, Agribusiness.

\section{INTRODUCTION}

Climate changes are facts that are occupying a relevant space in the scientificacademic, (industrial and agricultural) economical and political realms, as well as in civil society. The reasons for these concerns are related to the inadequate uses of soil, natural resources and minerals, hydrate and atmospheric pollution and deforestation. This has resulted in serious problems concerning the environment, such as floods, droughts, tornados and more severe hurricanes, elevation of the sea level, among others. (IPCC- Intergovernamental Panel on Climate Change, 2007; FAO - Food and Agriculture Organization, 2007).

This panorama is creating a paradoxical situation for agribusiness: the agro exporting countries will have problems in their production systems with the climatic changes (reduction of grain productivity due to the changes of the climatic precipitations, modification of soil fertility and losses in biodiversity). On the other hand, the generation of new market niches for agribusiness, such as reforestation, biofuel, carbon capture and new system mechanisms for natural resources are starting to foment new global business opportunities.

Davis and Goldberg (1957) when they created the concept of agribusiness as being the "sum total of all operations involved in the manufacturing and distribution of farm supplies; production operation on the farm; and the storage, processing and distribution of farm commodities and items made from". Thus, they point the need to picture these operations not in an isolated manner, but under a different point of view, giving the idea of an agroindustrial productive chain and placing the agricultural production as part of a much wider "commodity system”, emphasizing its relations with the world of large businesses.

The product development presuppositions of manufacturing companies are predominantly directed according to existent models of profitability, having as objectives the generation of commodities with high quality, low cost and high profitability. According to this logic, the environmental dimension tends to be considered as an additional cost and its insertion usually occurs only when it is considered essential, due to the pressures pointed out by authors.

Although many organizations consider the requirement to become green as a restriction, other organizations that are ahead of their time consider this requirement as an opportunity to maintain a sustainable competitive advantage (Porter and Van Der Linde, 1995; Steurer et al.2005 ), especially because of the emergence of new market niches. 
The new demand for environmentally correct products has brought new product standards and new business opportunities, causing a strong reflex on environmental legislation in order to modify internal processes in some industrial sectors and in agriculture. This environmental view has made the assimilation and integration of the environment and the socio-economic structure of the planet's development possible, allowing reconciliation between economic growth and environmental preservation to be not only possible, but also desirable, something considered impracticable until now.

These pressures generated by society and by the market have as a consequence the construction of new mechanisms and actions. Among these mechanisms, many can be highlighted, which is the case of the use of CDM (clean developments mechanisms), the handling of natural resources, the (organic) production and valorization, the obtainment of environmental certificates, sustainable reforestation, carbonic gas reduction procedures (Kyoto Protocol) and, mainly, more power given to the stakeholders. Regarding these actions, the influence of the stakeholders in the organizations becomes a prominent topic for researchers and society.

In this sense, the influences generated by the preoccupations of several stakeholders in the world provide several actions in the organizational, political, legislative and civil areas. However, various stakeholders present different interests, values and cultures, which could be a sign of the insufficiencies of the dialogue models related to the subject of climatic change. On the other hand, it could be offering an opportunity for the insertion of new comprehension mechanisms that could connect the goals of the stakeholders in common actions.

The reduction of government intervention opens new possibilities for more responsible forms of interaction between the stakeholders (Mellahi and Wood, 2003: Rondinelli and Barry, 2000; Banerjee, 2002). In Brazil, this situations are increasing the interventions, but there are many governments have been reluctant in facing the challenge, innovative and voluntary solutions have been implemented by organizations and communities (stakeholders) (IPPC, 2007). Thus, the insertion of different stakeholders related to the effects of climatic changes and its socio-economical and environmental business implication becomes necessary, especially considering the interfaces of different knowledge areas in new mechanisms that provide common alternatives.

During the last decade, there was a significant advance regarding the creation of mechanisms for the participation of society viewing the effects of climate changes. These stakeholders allow a greater inclusion of perceptions, knowledge and dialogue between different agribusiness stakeholders, in order for this situation to be reverted into new forms of coordination. However, these mechanisms still offer some limitations for the concrete occurrence of actions. Facing this scenario, the question is how to integrate the stakeholders in the production processes of agribusiness, in face of the climatic changes that are occurring. The issue researchs and show us different example about how to integrate the stakeholders. The objective of this essay is to propose a framework to include the agribusiness stakeholders in process of climatic changes.

In practical terms, this study deals with an emerging issue in which several stakeholders can dialogue through their experiences and carry out actions in favor of a goal which is the preservation of the environment. Deepening this scientific approach allows the control of organizational actions and inserts perspectives concerning the issue until then impossible to be analyzed.

The construction of sustainable relations between stakeholders requires investment of time and resources as well as availability by part of public and managerial sectors and the society to listen and learn with each other (Grayson; Hodges, 2002). In other words, the dialogues should be sustained in order to facilitate the growth of discoveries and establish commitments between stakeholders with common goals in favor of the environment. 
One of the concerns, farmers's agribusiness and policmakers are focused on the competition between food and biofuel. For example, the Co-op Insurance Society report indicates that $9 \%$ of the world's agricultural lands may be necessary to substitute the $10 \%$ that supplies world oil transportation. This means that the production of biofuels could lead to a decrease in the available land for food production and that it would be a specific problem in countries where food is already scarce (Griffin, 2007).

According to Griffin (2007), this could intensify the problem due to the fact that the population in the world should increase around 1 billion people until 2015 and in twenty years it will be necessary to increase $50 \%$ of the food production in order to feed the growing world population.

What cannot be classified in this contribution is the complex relation between food production, food prices and food security. Decades of experience has demonstrated that the increase of the food availability is not automatically related to the increase of food security, especially among the poor. Neither is the contrary true. In addition, food prices in the world market are only a limited extension in relation to food prices in local markets, especially in countries in development (Sande, 2008).

It can be verified that the big problem concerning biofuel is the food dilemma, but specifically of people that have an income of up to US\$2 a day. According to the human rights, everyone has the right to have adequate food and safety. In this sense, there is an important social-economical dimension together with the global foods problem. And in this context the notion of "rights to food" can provide some more concrete evaluation instruments of the degrees of competitiveness between food and biofuel (OENEMA, 2008).

In conclusion, the importance of relationships in networks along with the use of dialogues between stakeholders permits an advance into the development of more dynamic management models for organizations that seek sustainability.

This essay is structured in four parts. First, a theoretical review regarding the three approaches of the Stakeholders Theory, including the Science-Based Stakeholders Dialogues, Networks, and Theory of Conventions is presented as support for the proposed framework. The framework will be presented in the second part as soon as some examples, followed by the final considerations and, at last, the bibliographical references.

\section{BIBLIOGRAPHICAL REVIEW}

\subsection{Action of the stakeholders regarding climatic changes}

The participation of the stakeholders in environmental debates has favored the discussion of new themes locally, nationally and globally (NAE, 2005). Thus, the environment has progressively achieved more legitimacy among countries. It is important to point out that individual behavior represents a critical factor of the global climatic change. Therefore, the responsibilities should not only be given to industrial pollution, government failure or institutional inefficiency. (Fiqueres \& Ivanova, 2005).

In the Introduction to the Stakeholders Theory, first developed by Freeman (1984) and originated from the Firm Theory, he states that stakeholders are individuals or organizations that affect or are affected by objectives or problems, creating an infinite field of acting possibilities for stakeholders, and even for the climatic factors (Key, 1999). According to Bourne and Walter (2006) and Carrol (1989), the social science of the Stakeholders Theory tends to base itself in justice, equity and the social aspect, causing more impact on stakeholders that externalize moral reason through changes of initiative. These same authors, along with Donaldson and Preston (1995), clarify that the stakeholders' philosophy is 
legitimate and valid. They need to be identified; their powers and influences must be mapped, along with the potential impacts on the objectives.

Arguments from the point of view of environmental problems point out that the inclusion of the knowledge and perspectives of the stakeholders has developed different politics and researches (Kloprogee \& Van Der Sluijs, 2006). Before this concept of stakeholders, new scientific bases had emerged from the Learning Organization Theory (Senge, 1990) and the Science-Based Stakeholders Dialogues, especially related to climatic changes.

According to Welp et al., 2006a and Welp \& Stoll-Kleeman (2006), the Science-Based Stakeholders Dialogues is made of structures of the communicative process that unite researchers and stakeholders. According to the researchers, stakeholders have the necessary knowledge to assist the comprehension, representation and analysis of the global environmental changes, along with the decision makers, managers or other stakeholder models.

There are four necessary reasons for dialogues with the stakeholders: i) stakeholders play an important role in the relevant social identification and can scientifically change research issues; ii) scientists should make a real check-up of their researches and the stakeholders could be actively involved in the evolution of research methodologies and models to be used in researches, offering an evolution of the final results; iii) social science or facets of global changes researches limit scientific reasons and require the incorporation of ethical issues, respecting the different perspectives of different stakeholders; iv) the researcher's need of access to data and knowledge unknown until now. With the help of stakeholders, the researchers are able to obtain insights that can change the implementation and the visibility of the management of qualitative and quantitative procedures (Welp et al., 2006b).

This approach allows dialogues that can act as interfaces for different fields in the knowledge, climate changes and agribusiness areas, due to its large systemic capacity. There are still three main types of guided dialogues: political dialogues (Innes \& Boother, 2003), Multi-Stakeholders Dialogues For Governments (Hemmati, 2002) And Corporative Dialogues (Jesper, 1998).

However, the Science-Based Stakeholders Dialogues are more complete, due to its constructive extent that allows an exchange between learning, experiences and opinions, which are part of the process of constructing dialogues for climatic changes.

This approach is initially concerned with which stakeholders will be contacted for the beginning of the process. The preferences, interests and priorities of the research will interfere in the selection process. However, to avoid problems in future dialogues, Biernacki and Walforf (1981) have developed a stakeholders data program that identifies, through certain characteristics, the most relevant stakeholders for the process.

In this form of joint communication, it is necessary to dominate the operational forms. Welp et al (2006b) have identified two types of instruments for the dialogues among stakeholders - communication instruments and analytical instruments.

The communication instruments range from the use of the Internet, workshops, seminars, meetings and circular e-mails to softwares of climatic changes (game called "Winds of Change" developed by the Munich Reinsurance Company and "Keep Cool", another game developed by the ECF - European Climate Forum, in which players make decisions for each region of the planet) (Hasselmann et al., 2003; European Climate Fórum, 2004; Welp et al., 2006b).

The analytical instruments are used to complement and support the communication instruments. The first allows the participants to have an active and real engagement towards the climatic changes, for there is a sensibilization among different stakeholders that cause 
positive results among the involved sectors. There are other analytical instruments, such as Integrated Evaluation, Potential Vulnerabilities for Climatic Changes, AHP (Analytical Hierarchy Process), Coalition Method of Stakeholders Defense and Social Carbon Methodology.

The Integrated Evaluation (IE) presented by Kloprogge and Van Der Sluijs (2006) emerges as a tool to integrate adequate actions for the arrangement of uncertainties, complexities and different values regarding environmental risks. There are uncertainties in both of these situations: mechanisms of climatic systems and development of the social future. The involvement of the stakeholders in the IE process is relatively recent, since the IE regarding climatic changes has been completely dominated by researchers of natural sciences and by computer programs. This process allows the identification, articulation and the incorporation of specific and non-specific knowledge in the perspective of causes, effects, relevant aspects and problem solutions.

This approach is developed through a new tool of impact evaluation for climatic changes identified as Potential Vulnerabilities for Climatic Changes, presented by Jones (2001). The author highlights the management of uncertainties that follow the scenario of climatic changes through sequences of climatic impacts in the context of biophysics and in socioeconomic aspects. The method of analysis is guided by the IPCC, which orients the impact variables for climatic changes and the allowed adaptations for the identification, evaluation and implementation of adaptation procedures involving stakeholders.

In this model, the insertion of the stakeholders is centrally involved by the following variables: main climate factors, scenarios, sensibility analysis, threshold, risk analysis, autonomous adaptation, planned adaptation and the IPCC. The inclusion of the knowledge and perception of the stakeholders bases the active debate on reliability relations since they are supported by policies regarding the effects of climatic changes (Kloprogge \& Van Der Sluijs, 2006).

The AHP (Analytical Hierarchy Process) is a mathematical method for the analysis of multi-criterion problems (Saaty, 1990). The Coalition Method of Defense presented by Sabatier and Jenkins-Smith (1993) is used to explain the behavior and the policies of stakeholders after intense conflict periods. The Social Carbon Methodology follows the same idea. It is an evaluation and accompanying analytical tool that guarantees the transference of social and economical benefits to the communities that are situated in the areas where the projects of sequestering and reduction of carbon are introduced (Rezende \& Merlin, 2003).

Gemmill and Bamidele-Azu (2005) have taken into consideration the following aspects of their experiences: dialogues do not necessarily have to be consensus for the utility of the proposed objectives, although a process conceived to include different stakeholders will reflect a larger horizon of points of view and can also generate more creative approaches for problem solving; a process in which the participants who come from different spheres have an equal partnership in the same project has more chances to produce useful results.

The next part of the article will portray the Network approach and its way of dealing with the information and commitments generated from dialogues with the stakeholders.

\subsection{Environmental issues forming Networks}

Network Analysis is seen as a sub-type of the general structure of Structural Sociology. Structural Sociology is an approach in which the social structures, constrictions and opportunities have more effect on human behavior than on cultural norms and other subjective states (Castells, 2000).

According to Brinkerhoff (2002), Network evaluation is based on five pre-requisites and success factors, which are: pre-requisites on reputation (tolerance of the division of power 
between partners and interpersonal and technical abilities, etc.); partnership degrees (reciprocity, resource exchange, organizational identity); development of organizational connections (added values, partners with objectives, partnership identities); partnership development; efficiency and strategy.

From the analytical point of view, the study of authorities inside the Networks is crucial not only for understanding who is making the strategic decisions, but also to identify the means in which the strategy is executed. According to Brinkerhoff, two dimensions are prominent to define a partnership and to distinguish it from two other kinds of relations: mutuality and identity. The first refers to mutual dependence, to the rights and responsibilities of each actor in relation to others. These rights and responsibilities aim to maximize the benefits for each part and can be limited due to common objectives. It is usually assumed that the creation and the maintenance of an organizational identity are necessary for long-term success.

Regarding aspects related to the environment, the networks vary according to its performance considering factors of scheduling, standards, knowledge diffusion and generation, institutional effectiveness and innovated implementation mechanisms (Streck, 2005). These types of networks present themselves internationally and conjugate the volunteer legitimacies of the stakeholders, such as financial, public, cultural and legislative interests. They also present a possible strategy so that stakeholders with different interests and values can approach the challenges of interdependence and global environmental issues in a participative and supportable way.

It can be verified that the networks are recent contributions to the sustainable coordination systems (Streck, 2005). The cited author affirms that the networks with environmental issues possess two principles, which are: a) the ability to respond to urgent environmental problems; b) because of the non-hierarchy structure and the multiple stakeholders, they can overcome the deficiency caused by the participation of some stakeholders.

Due to these two principles, the network generates much more benefits from what is provided and fills a gap with the Theory of Conventions with the purpose of analyzing which coordination is supporting the environmental collective resolutions in the networks formed by dialogues with stakeholders.

\subsection{Theory of Conventions}

The objective of the Theory of Conventions is to build a theoretical and interdisciplinary framework that permits the approach of the general issue of the collective coordination regarding individual actions through conventions (Orléan, 1994). The Theory of Conventions approach presents elements of open coordination regarding uncertainties, critical tensions and creative arrangements, rather than ideas regarding a reproductive and established order (Thevénot, 2001).

According to Thevénot (1989, 2001), the universe of human actions is fundamentally complex and in each instant it is possible to refer to various conceptions regarding the same good. The coordination is based on categorized characteristics of human beings, such as identities, interest groups, habits, etc. In this sense, the results of the confrontations between these different social groups are complex and conflicting, which results in many ways of coordination. The plurality of the ways of coordination occurs through a set of references of a collective cognitive process that forms mechanisms of coordination among the actors.

Based on a set of general principles of coordination and on classical masterpieces of Political Philosophy, Boltansky and Thevénot (1987) have identified six types of 
justifications, to which correspond six states of the nature that justifies many other justifiable actions: inspiration, domestic, opinion, civic, mercantile and industrial.

The nature of inspiration is based on the actors' adherence to the emergence of original and innovating ideas while quality is based on innovation and modernity. The domestic nature has as common superior principle the relations which are based in tradition, thus, it establishes the hierarchy levels given by relations of reliability, habit and fidelity among people; investment comes from a sense of duty and rejection of selfishness. In the nature of opinion, opinion is the common superior principle and the magnitude of order is given by notoriety, recognition or success.

Regarding the civic nature, the common superior principle is the union of all natures to form the general will: public, collective, legal, representative, rights, civic rights, legislative, supportive, union, codification, democracy, fair commerce and environmental issues. The mercantile nature has as common superior principle the competition among goods; the magnitude of the subjects is given by material wealth, while dignity is given by interests in profit, market, free prices or the motivation to obtain personal satisfaction.

At last, the industrial nature is characterized by effectiveness and investment as the best economic formula to obtain efficiency. Some attributes of this nature are: specialization, professionalism, performance, procedure, norm, strategy, standard and planning.

If we consider, in agreement with the authors, that people act according to good reasons (behavior reasoning) and that there is a coordination (justifiable action) that permits equilibrium, then a general framework of justifiable actions and individual behaviors can be outlined according to different models of nature.

\section{Convergence among the used theoretical approaches}

In Figure 1, it is possible to visualize how the consolidation of the three approaches interact among each other and how the conventions are identified through networks formed by the dialogues between stakeholders regarding climatic issues, since the objective is to comprehend how the dialogues between stakeholders are formed, how science supports these perspectives, how the actions of these stakeholders form networks and which conventions support the networks.

FIGURE 1. Consolidation of Stakeholders Theory, Networks and Theory of

Conventions approaches regarding agribusiness and climatic changes.

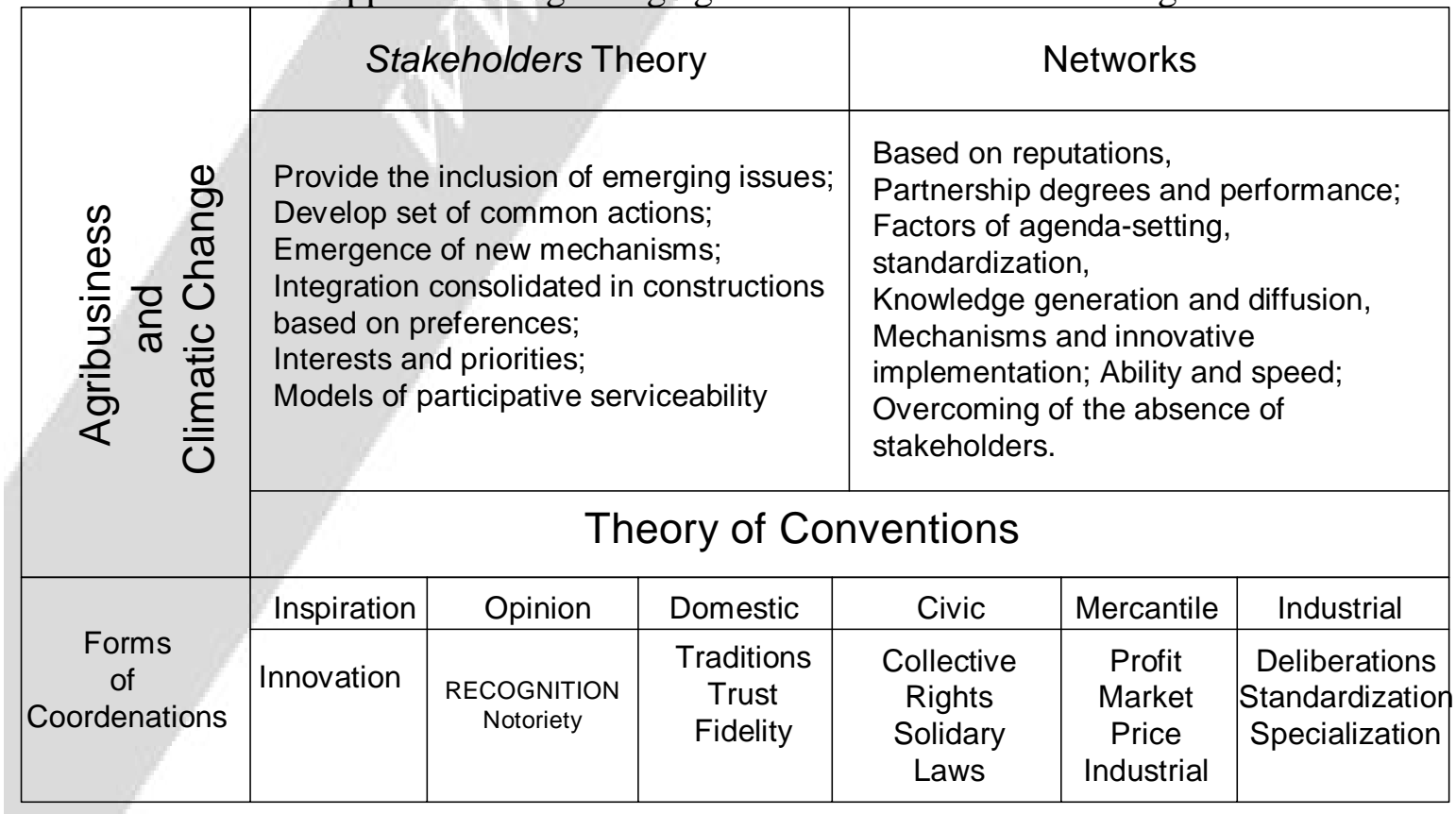

(C) RGSA - v.4, n.1, jan./abr. 2010 
Source: Elaborated by the authors.

Moreover, this framework portrays how the synergies between the three approaches occur. It can be observed that the stakeholders begin the dialogue process by offering information for the formation of networks. The Theory of Conventions justifies each action generated in a systemic and participative way. The common points between the Stakeholder and the Network approaches are the ease to include emerging themes, degree of action among partnerships, knowledge diffusion, innovating mechanisms and common interests.

\section{EXAMPLES THAT COULD SUGGEST USING THE FRAMEWORK}

In this phase, an analysis was carried out of the possibilities of these interactions through a multifaceted view of the researches that used the stakeholder dialogue approach as basic thread for the development of organizations of any nature. In this case, only articles related with agribusiness were studied. Table 1 was therefore designed to identify the typology of the stakeholders and the coordination of each project.

The information contained in Table 1 lays the base for partnerships and seeks to develop solutions that meet the expectations of every stakeholder and are therefore are to signalize the formation of networks concerned with solving specific conflicts.

These articles, observed according to table 2, have demonstrated some networks that were formed and their confirmed consolidations, such as: creation of policies for the rational use of water; creation of management mechanisms in order to increase the capacity of carbon sequestration; participative management; and new technologies in favor of the environment but without due support of a network theory.

TABLE 1. Characterization of the 5(five) selected articles demonstrating agribusiness cases

\begin{tabular}{|c|c|c|c|c|}
\hline Case & Country & Reference & Coordenation & $\begin{array}{l}\text { Tipology } \\
\text { Stakeholders }\end{array}$ \\
\hline $\begin{array}{l}1 \text { Eakin et al. } \\
(2007)\end{array}$ & México & $\begin{array}{l}\text { Use od water in } \\
\text { agribusiness }\end{array}$ & $\begin{array}{l}\text { UNAN (National } \\
\text { Autonomous } \\
\text { University of Mexico) } \\
\text { e Colegio de Sonora }\end{array}$ & $\begin{array}{l}\text { Water resources managers, } \\
\text { rural unions, local } \\
\text { environmental institutions, } \\
\text { non-governmental agencies, } \\
\text { researchers, rural producers, } \\
\text { entrepreneurs } \\
\text { (approximately } \\
\text { stakeholders). }\end{array}$ \\
\hline 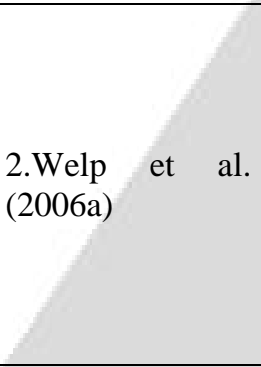 & Germany & Florest Management & $\begin{array}{l}\text { PIK (Potsdam Institute } \\
\text { for Climate Impact } \\
\text { Research) -Líder } \\
\text { SILVISTRAT } \\
\text { (Silvicultural } \\
\text { Response Strategies to } \\
\text { Climate Change in } \\
\text { Management of } \\
\text { European Forests) }\end{array}$ & $\begin{array}{l}\text { Forest-based sector } \\
\text { companies, civil servants, } \\
\text { wood industry, researchers, } \\
\text { NGOs, tourism, water and } \\
\text { local rural community } \\
\text { coordinators. }\end{array}$ \\
\hline 3. Linke (2006) & Equador & $\begin{array}{l}\text { Sustentability of } \\
\text { natural resources of } \\
\text { forest management }\end{array}$ & $\begin{array}{l}\text { GTZ (Gesellschaft fur } \\
\text { Technische } \\
\text { Zusammnarbeit) }\end{array}$ & $\begin{array}{lr}\text { Palm oil/cocoa/banana agro- } \\
\text { industry, wood industry, } \\
\text { afro-equatorial and } \\
\text { indigenous communities, } \\
\text { catholic church, } \\
\text { universities, 9 NGOs, } 7 \\
\text { international agencies. }\end{array}$ \\
\hline
\end{tabular}




\begin{tabular}{|c|c|c|c|c|}
\hline $\begin{array}{l}\text { 4.Kloprogge e } \\
\text { Van Der Sluijs } \\
\text { (2006); Tuinstra } \\
\text { et al. (2002) }\end{array}$ & Holland & $\begin{array}{l}\text { Reduction of GEE - } \\
\text { of sector of } \\
\text { agriculture, } \\
\text { agribusiness, } \\
\text { transport } \\
\text { construction. and }\end{array}$ & $\begin{array}{l}\text { COOL (Climate } \\
\text { Options for the Long- } \\
\text { Term) }\end{array}$ & $\begin{array}{lr}18 \text { NGOs, } 8 \text { governmental } \\
\text { organizations, } 5 \text { advisors, } 2 \\
\text { public energy corporations, } \\
2 \quad \text { local leaders, } & 14 \\
\text { researchers, } & 17 \\
\text { entrepreneurs } & \\
\text { (approximately } & \\
\text { stakeholders). }\end{array}$ \\
\hline $\begin{array}{l}\text { 5. Rezende } \\
\text { Merlin (2003) }\end{array}$ & $\begin{array}{l}\text { Brazil } \\
\text { (Ilha do } \\
\text { Bananal) }\end{array}$ & $\begin{array}{l}\text { Aproveitamento } \\
\text { sustentável dos } \\
\text { recursos naturais do } \\
\text { cerrado no contexto } \\
\text { do carbono social }\end{array}$ & Instituto Ecológica & $\begin{array}{lr}8 & \text { governmental } \\
\text { organizations, } & 7 \text { research } \\
\text { centers, } 8 & \text { financers, } 2 \\
\text { universities, } & \text { local } \\
\text { communities, } & \text { indigenous } \\
\text { people, } 5 \text { city halls. }\end{array}$ \\
\hline
\end{tabular}

Source: Elaborated by the authors.

TABLE 2. Presentation of the five articles observed, along with the methods used, objectives and deliberations.

\begin{tabular}{|c|c|c|c|}
\hline Case & Method & Objective of the dialogues & Deliberations \\
\hline $\begin{array}{l}1 \text { Eakin et } \\
\text { al (2007) }\end{array}$ & $\begin{array}{l}\text { Avaliação } \\
\text { Integrada }\end{array}$ & $\begin{array}{l}\text { Excessive and irrational use of water in the } \\
\text { semiarid region of México; Impact of climate } \\
\text { variability in the use of water by agribusiness } \\
\text { sectors. }\end{array}$ & $\begin{array}{l}\text { Promote water culture among users } \\
\text { in order to reduce the demand for } \\
\text { water and improve the policy for } \\
\text { consciousness rising of water } \\
\text { scarcity; improve the use of water in } \\
\text { the civil construction industry } \\
\text { (modern houses with sustainable } \\
\text { energy and water systems); } \\
\text { rainwater capture for the productive } \\
\text { sector; reduction of irrigation } \\
\text { systems in agriculture. }\end{array}$ \\
\hline $\begin{array}{l}\text { 2.Welp et } \\
\text { al (2006a) }\end{array}$ & $\begin{array}{l}\text { Combination of } \\
\text { analitical } \\
\text { instruments (AHP- } \\
\text { Analytical } \\
\text { Hierarchy Process) } \\
\text { and comunications } \\
\text { (workshops, } \\
\text { questionários, } \\
\text { entrevistas) }\end{array}$ & $\begin{array}{l}\text { Create strategic forest management } \\
\text { mechanisms for mitigation; use of carbon } \\
\text { sequestration as a form of investment. }\end{array}$ & $\begin{array}{l}\text { Modeling of the impacts of different } \\
\text { managements and climatic scenarios } \\
\text { in the forest; evaluation of the } \\
\text { effects of the impact in terms of } \\
\text { costs and benefits in order to } \\
\text { increase the capacity of carbon } \\
\text { sequestration. }\end{array}$ \\
\hline $\begin{array}{l}\text { 3. Linke } \\
(2006)\end{array}$ & $\begin{array}{l}\text { Integrate } \\
\text { Participations and } \\
\text { Analyses } \\
\text { Constelation of } \\
\text { Stakeholders } \\
\text { (Sabatier } \\
\text { Jenkins-Smith, e } \\
\text { 1993) }\end{array}$ & $\begin{array}{l}\text { Natural resource management; search for } \\
\text { experiences of cooperation between } \\
\text { communities and several institutions; } \\
\text { availability to promote information through } \\
\text { reciprocal coordination. }\end{array}$ & $\begin{array}{l}\text { - Creation of temporary or } \\
\text { permanent forums and platforms: } \\
\text { creation of networks with different } \\
\text { stakeholders; participative planning, } \\
\text { promotion putting in evidence local } \\
\text { stakeholders' needs and interests; } \\
\text { insertion of the stakeholders' } \\
\text { perception and knowledge in the } \\
\text { process of building a natural } \\
\text { resources management of the } \\
\text { equatorial forest. }\end{array}$ \\
\hline $\begin{array}{l}\text { 4.Kloprogg } \\
\text { e and Van } \\
\text { Der Sluijs } \\
\text { (2006); } \\
\text { Tuinstra et } \\
\text { al (2002) }\end{array}$ & $\begin{array}{l}\text { Integration } \\
\text { Avaliation }\end{array}$ & $\begin{array}{l}\text { Promote the development of insights and } \\
\text { recommendations for the international climate } \\
\text { change policy of Holland for the reduction of } \\
\text { greenhouse gas emission to } 50-60 \% \text { until } 2050 \\
\text { (1990 levels) }\end{array}$ & $\begin{array}{l}\text { Agriculture sector: use of organic } \\
\text { fertilizers, use of closed stables, } \\
\text { construction of neutral CO2 } \\
\text { greenhouses, optimization of wood } \\
\text { consumption chains (reduction of 6- } \\
8.5 \text { megatons of CO2 (23-35\% of } \\
\text { the average emission in } 1990) \text {, } \\
\text { implementation of measures to } \\
\text { reduce } 12-18 \text { Megatons of CO2/eq } \\
\text { ( } 60-80 \% \text { of these compared with the } \\
\text { levels in } 1990 \text {, } 5-10 \mathrm{Mt} \mathrm{CO} / \mathrm{eq}) \text { of } \\
\text { the primary production }\end{array}$ \\
\hline
\end{tabular}




\begin{tabular}{|l|l|l|l|}
\hline Case & Method & Objective of the dialogues & Deliberations \\
\hline $\begin{array}{l}\text { 5.Rezende } \\
\text { and Merlin } \\
\text { (2003) }\end{array}$ & $\begin{array}{l}\text { Method of Social } \\
\text { Carbon }\end{array}$ & $\begin{array}{l}\text { Preservation of the natural ecosystem in order } \\
\text { to reduce the rate of deforestation in degraded } \\
\text { areas; income generation for the communities } \\
\text { involved. }\end{array}$ & $\begin{array}{l}\text { Commercialization of sweets, jams, } \\
\text { liquors and spices, implantation of } \\
\text { agro-forest systems in the savanna, } \\
\text { obtainment of organic certifications, } \\
\text { seedling nursery, teacher training, } \\
\text { inventory of forest species, studies } \\
\text { of the biomass and carbon stock in } \\
\text { the savanna. }\end{array}$ \\
\hline
\end{tabular}

Source: Elaborated by the authors.

The networks demonstrated supply the tools for enabling an evaluation of which conventions are supporting each action of the Network. All justifications (opinion-based, inspirational, industrial, market, civic and domestic) of coordination actions could be evidenced in the five articles studied.

However there were no conditions for measuring them in degrees of importance and it was only possible to identify some fundamental variables for each action. Consequently, these previous analyses with the perspective of the conventions theory were not explored in the articles analyzed. a) Opinion-based and Inspirational Conventions. It is more convenient to visualize the two as a set, due to the small amount of information. However, it can be said that: i) Climate change needs innovation in order to solve mitigation problems; ii) The reputation of responsible institutions is valued due to their history, tradition and proved actions (PIK, COOL, GTZ, UNAM and Ecologic Institute) and reinforces the inclusion of stakeholders; iii) Emergence of original and innovative technology is present in each case (rainwater capture, modeling systems, creation of forums and platforms, reduction of GHG, social carbon). b) Industrial Convention. i) Each deliberation analyzed predicts new forms of agreements, protocols and common norms among stakeholders of the participant network. Each institution verifies the capability of each participating stakeholder, thus the importance of the mechanism to propitiate the correct choices to stakeholders; ii) It was verified that there are many productive sectors inserted in the dialogues. This insertion demonstrates the agroindustrial sector's great interest in dialogue (forest-based production chains, palm oil, cocoa, banana and transportation and construction sectors).

c) Civic convention. i) Is interconnected to social-cultural awareness of values such as environmental concerns; ii) Structures an economic relation based on sustainability with the use of environmental certifications; iii) Builds universal concepts through principles of sustainable development (analytical tools: social carbon, integrated assessment, constellation analysis, etc.). d) Domestic convention. i) Presents relations of trust and loyalty among stakeholders; ii) the need to help each other overlaps economic aspects for several reasons, such as the survival of the natural system and permanence of the agribusinesses' productive sectors. e) Market convention. i) There are economic purposes in some participative stakeholders due to these organizations' (industries) search for raw material, in other words, natural resources, which are the base of theirs products and survival.

Therefore, it can be noticed that the conventions introduce justifications and that the networks formed could create mitigation mechanisms pointing to guidelines for the framework proposed.

To the negotiations and conflicts confer the existence of differentiated degrees and differentiated interests that vary from stakeholders and the regions where they are located. Through this exercise, it can be noticed that the conflicts and negotiations are present, meeting the process of dialogue as well as the resolutions that could be made toward mitigation. 
In other words, these pre-analysis indicate elements that could be used for the construction of the proposed framework, due to the fact that they admit that the theoretical bases have fundamental elements for the development of the proposed framework.

\section{PROPOSED FRAMEWORK: INSERTION MECHANISMS FOR AGRIBUSINESS STAKEHOLDERS IN CLIMATIC CHANGES}

In order to introduce the framework, it is important to review some dialogues issues: the necessity should be diverse and plural among the researchers and the stakeholders, because it has been noticed that in some moments, the dominance of the discourse is disconnected between them. According to Rorty (1991), the scientific methods are seen as a guarantee for the quality of the arguments, since the author observes that science is a form of dialogue between undistinguished and privileged paths. According to Maturana and Varela (1998), there is not a monopoly of rights to knowledge, but a reflection of personal intuitions that are equally true.

These thoughts can be observed in the work of Putman (2002) about the exchange of arguments and conversations that become crucial for society and science, mainly in the middle of negotiations regarding the effects of global climatic changes. Examples of cases from the IPCC (Reason, 2002) and the European Climate Forum, 2004 intend to demonstrate the importance of the relevance of dialogues between stakeholders for both science and society.

According to Pohl (2005), trans-disciplinary researches solve complex problems such as biodiversity loss and climatic changes, mainly where discipline research fails to solve. This line of thought introduces the relevance of stakeholders in agribusiness, since the collaboration between research institutions, industries and private sectors is highly crucial to propose solutions for mitigations. The construction of a framework intends on bringing the theory closer to reality, regarding future investigations.

The framework proposed in Figure 2, entitled "Insertion Mechanisms for Agribusiness Stakeholders in Climatic Changes", will try to establish a portrait of how the process regarding insertion of stakeholders in the agribusiness environment - having climatic changes as its problematic - permits a view of the real situation and how the forms of networks and conventions can contribute to the equilibrium process by delineating a framework of individual behavior with specific nature creating alternatives for mitigation and opportunities for agribusiness.

FIGURE 2. Framework: Insertion Mechanisms for Agribusiness Stakeholders in Climatic Changes

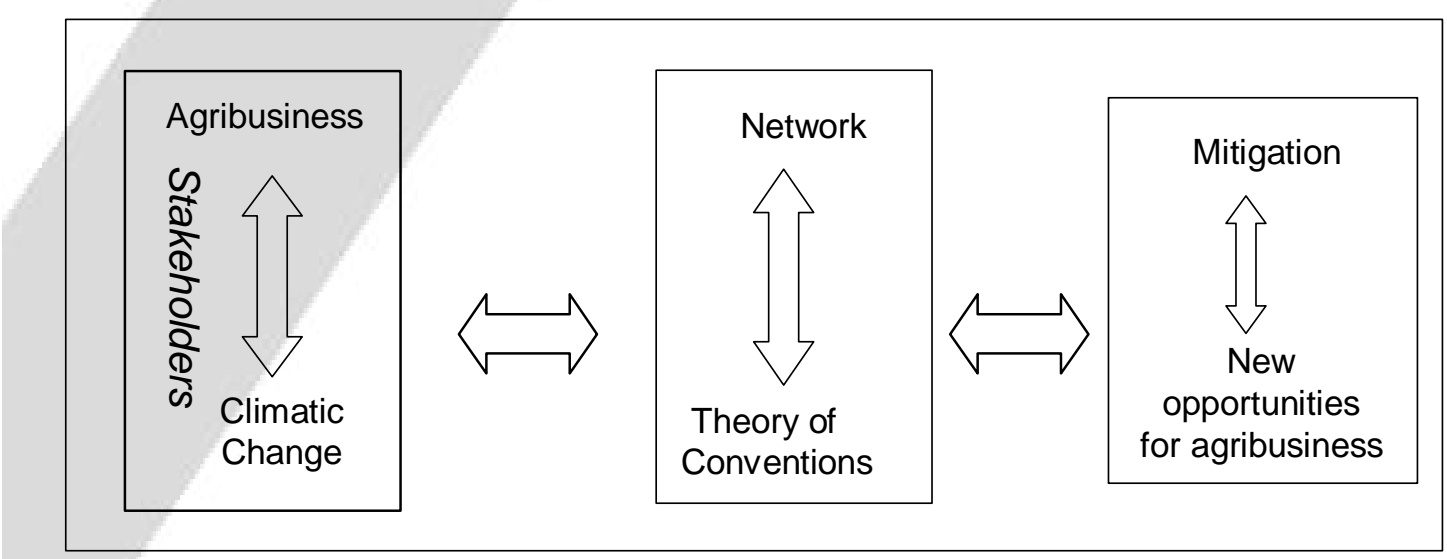

Source: Elaborated by the authors

(C) RGSA - v.4, n.1, jan./abr. 2010

www.gestaosocioambiental.net 
The figure 3 demonstrates the variables that will be investigate for consolidation of framework.

FIGURE 3. Relevant factors of the approaches proposed in the research.

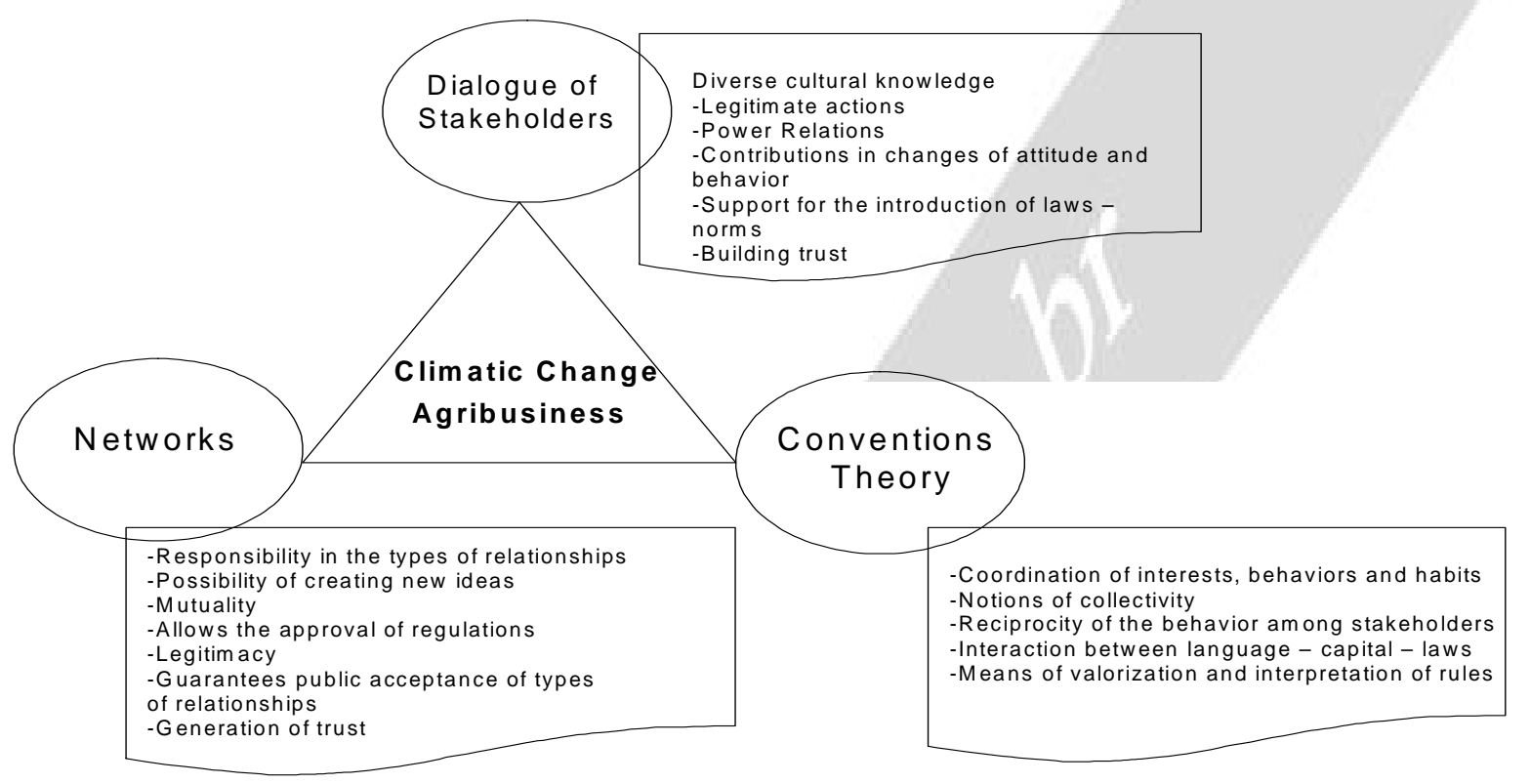

Source: Elaboraded by authors

In addition, it can be noticed that the stakeholders are the main agents and guides of the intersection process of agribusiness sectors. The dialogues between agribusiness stakeholders concerning climatic changes are not static and this is the reason the three variable sets (stakeholders, agribusiness and climatic changes) should be systematically studied. The results of these cooperations (dialogues) provide the information for the network construction that intends to structure, capture and mold a new mechanism. As the network becomes consolidated, the theoretical bases of the Conventions justify each action generated inside the process and assist in the proposal of solutions for mitigation and opportunities regarding climatic changes, the examples are visualized on Table 1 and Table 2.

The elements of the framework can help in the implementation of sectors in agribusiness and in networks that search for solutions for the environment and can even introduce, clearly and objectively, a way to work with the discussions. The operation of the framework counts with two tools for its effectiveness: communicational and analytical.

The Theory of Conventions focuses on how the coordination is established among stakeholders, reconstructing its representations, and, according to Wilkinson (1997), establishes a path to other current analysis of social sciences, especially with actors and new approaches of economical sociology. According to Biggart and Beanish (2003), the theory of conventions is related to habits, customs and practices of standards that are similar to tacit levels and serve to organize the coordinations. The Theory of Conventions explains the economic coordination between the stakeholders that are collectively interconnected in their social, economical and cultural dynamics.

The purpose of using the Theory of Conventions is the possibility to build beyond the economic aspect, even if this interest is only apparent, since climatic changes in agribusiness provide opportunities and limitations for the productive sectors. 


\section{CONCLUSION}

The objective of this study was to make a theoretical analysis of the insertion of stakeholders in the area of climatic changes in agribusiness and to propose a framework identifying mechanisms that allow the inclusion of stakeholders in the process of climatic changes.

The approach of Stakeholders Dialogues has the purpose of responding to this, since this approach adds meanings, new introspections and different technological verves regarding causes and effects - to information.

Strong objectives were identified among the stakeholder perspectives, such as prominent quality, obtainment of citizen support, legitimacy and democracy. These variables offer the apparatus for contributing democratically with the politics and duties of public organs and, regarding the environment, strengthens coordination and contribution factors.

The proposed framework is an open and active mechanism that permits the inclusion of various stakeholders. However, the capacity to determine which stakeholders are relevant for the process is necessary and, for that, they must be refined and carefully selected. Existing conformity regarding the functions of the stakeholders, the search for answers and alternatives related to the causes and effects of climatic changes becomes a function of the total collectivity, mainly because of the exchange of arguments and the creation of a common sense. The dialogues demonstrate that partnerships based on reliability are fundamental, justifying the mutuality in networks.

The integration of actions from stakeholders in agribusiness will occur according to the forms of conventions based on networks structured through reliability and real data. It is possible to verify inside agribusiness that these actions are already occurring and are being consolidated in different sectors of the economy, according with the case studies presented.

It can be concluded that the actions among stakeholders of agribusiness presented in this study offer different coordination forms regarding the effects of climatic changes. It could still be possible for these forms of coordinations to face the challenge of seeking alternatives even more supportable for the environment, mainly for the production of market niches and for commodities productive chains.

This study provides a framework for future researchers, which involves analysis and constructions of networks among stakeholders and production chains of agribusiness on behalf of the environment that could be the beginning of a sustainable agribusiness.

\section{REFERENCES}

Banerjee, S. B. (2002). Contesting Corporate Citizenship, Sustainability and Stakeholders Theory: Holy Trininty or Praxis of Evil? 2002. Retrieved June 13, 2007 from: http:/business.unisa.edu/au/cae/TBL/tbldownloadables/banerjeecorporateresponsibility.pdf.

Biernacki, P.,\& Waldorf, D.(1981). Snowball Sampling: Problems and Techniques of Chain Referral Sampling. Sociological Methods and Research, 10 (2), 141-163.

Biggart, N.W.,\& Beamish, T.D.(2003). The Economic Sociology of Conventions: Habit, Custom, Practice and Routine in Market Order. Annual Review of Sociology, 29, 442-464.

Brinkerhoff, J. M. (2002). Assessing and improving partnership relations and outcomes: a proposed framework. Evaluation and Program Planning,(25), 215-231.

Boltanski, L.,\& Thevenot, L.(1987). Les économies de la grandeur, Cahiers du centre d'études de l'emploi, 31 Paris: Press Universitaires de France.

(C) RGSA - v.4, n.1, jan./abr. 2010

www.gestaosocioambiental.net 
Bourne, L.,\& Walker, D.(2006).Visualizing stakeholders influence: Two australian Examples. Project Management Institute, 37(01), 5-21.

Carrol, A.B.(1989). Business and society: ethics and stakeholders management, SouthWestern:Publishing, Cincinnati, $\mathrm{OH}$.

Castells, M. (2000). The rise if the network society, Blackwell, Malden, MA, ed.2.,594p.

Campos, C.P.A.(2001). Conservação das Florestas no Brasil, Mudança do Clima e o Mecanismo de Desenvolvimento Limpo do Protocolo de Quioto. (Dissertation Master, Energetic Planning, PPE/COPPE/UFRJ, Rio de Janeiro).Dissertation Master.

CMMAD - Comissão Mundial sobre Meio Ambiente e Desenvolvimento Comissão Mundial sobre Meio Ambiente e Desenvolvimento.Nosso Futuro Comum, New York: ONU.1987.

Donaldson, T.,\& Preston, L..E. (1995). The stakeholder theory of the corporation: concepts, evidence and implications. Academy of Management Review, 20 (1), 65-91.

ECONOMISTS OF CLIMATE. Volume I Report. Select committee on Economic Affairs. 2nd Report of Session 2005-2006. Retrieved June 2007 from:http://www.parliament.uk/parliamentary_committees/lords_economic_affairs.cfm.

EUROPEAN CLIMATE FORUM (2004) What is dangerous climate change?. Initial results of a Symposium on Key Vulnerable Regions and Climate Change and Article 2 of the UNFCCC, Buenos Aires, 14 December. Retrieved June 8, 2007 from:http://www.european-climateforum.net/pdf/ECF_beijing_results.pdf.

FAO - Food and Agriculture Organization. Adaptation to climate change in Agriculture, forestry and fisheries: perspectives, framework and priorites. Retrieved June 8, 2007 from:http:// www.fao.org.

Figueres, C.,\& Ivanova, M.H.(2005).Mudanças climáticas:interesses nacionais ou um regime global? In: Esty, D.,\& Inavona, M. H. (eds.), Governança Ambiental Global:Opções $e$ Oportunidades,Senac:São Paulo, 301p.

Freeman, R.E.(1984) Strategic management: a stakeholder approach. Boston: Pitman / Ballinger.

Gemmill, B.,\& Bamidele-Izu, A.(2005). O papel das ONG e da sociedade civil na governança ambiental global. In: Esty, D.,\& Inavona, M.H.(eds.), Governança Ambiental Global:Opções e Oportunidades,São Paulo:Senac, 301p.

Hasselmann, K., Latif, M., Hooss, G., Azar, C., Edenhofer, O., Jaeger, C. C., et. al. (2003). The Challenge of Long-term Climate Change. Science, 302, 1923 - 1925.

Hemmati, M.(2002). Multi-Stakeholder Processes for Governance and Sustainability—Beyond Deadlock and Conflict. London: Earthscan.

IPCC. (2007) Fourth Assessment Report Climate Change 2007: Mitigation of Climate Change. Summary for Policymakers, Working Group III, p. 35.

Innes, J.E.,\& Booher, D.E.(2003). Collaborative policymaking: governance through dialogues, In: Hajer, M.A., \& Wagenaar, H. (Eds.), Deliberative Policy Analysis: Understanding Governance in the Network Society. Cambridge: Cambridge University Press. 
Jesper, G. (1988). Corporate legitimacy in risk society: the case of the Brent Spar. Business Strategy and the Environment, 7, 213-222.

Jones, R.N. (2001). An Environmental Risk Assessment / Management Framework for Climate Change Impact. Natural Hazards, 23, 197-230.

Key, S.(1999). Toward a new Theory of the firm: a critique of stakeholder "theory". Management Decision, MCB University Press, 37(4), 317-328.

Kloprogee, P.,\& Van Der Sluijs,J.P. (2006).The Inclusion of Stakeholders Knowledge and Perspectives in Integrated Assessment of Climate Change, Climatic Change, 359-389.

Maturana, H.R.,\& Varela, F.J.(1998). The Tree of Knowledge: The Biological Roots of Human Understanding, Shambhala Publications.

Mellahi, K.,\& Wood, G.(2003). The Role and Potencial of Stakeholders in Hollow Participation: Conventional Stakeholders Theory and Institutional Alternatives. Business and Society Review, 108(2), 183-202.

NAE. (2005). Núcleo de Assuntos Estratégicos da Presidência da República. Núcleo de Assuntos Estratégicos da Presidência da República, Brasília: Secretaria de Comunicação de Governo e Gestão Estratégica 3, fev.

Orlean, A.(1994).Vers un modèle générale de la coordenation économique par les conventions', In A. Orléan (eds.), Analyse économique des conventions. Paris: Presse Universitaires de France.

Putnam, H.(2002). The Collapse of the Fact/Value Dichotomy and Other Essays. Cambridge: Harvard University Press, MA.

Porter, M. E., \& Van Der Linde, C. (1995). Green Competitive: Ending the Stalemate. Harvard Business Review, 120-134.

Pohl, C (2005). Transdisciplinary collaboration in environmental research. Futures, 37, 1159-1178.

Reason, P.(2002). The practice of co-operative inquiry. Systemic practice and Action Research, 15, 169-176.

Rezende, D., \& Merlin, S.(2003). Social Carbono:adding value to sustainable development. Instituto Ecológica. São Paulo: Peirópolis ,160p.

Rorty, R.(1991). Solidarity or objectivity? In: Rorty, R. (eds.), Objectivity, Relativism and Truth, Cambridge University Press, Cambridge, p. 21-34.

Rondinelli, D.A. \& Berry, M.A.(2000). Environmental Citizenship in Multinational Corporations:Social Responsibility and Sustainable Development. European Management Journal, 18(1), 70-84.

Saaty, T. L. (1990). Multicriteria Decision Making, The Analytic Hierarchy Process, Planning, Priority Setting. Pittsburgh: Resource Allocation, RWS Publications.

Sabatier, P.A.,\& Jenkins-Smith, H.C.(1993). Policy Change and Learning An Advocacy Coalition Approach. Colorado: Westview Press, Boulder/Colorado, USA. 
Senge, P. (1990) The Fifth Discipline. The Art and Practice of the Learning Organisation. Doubleday, New York.

Streck, C.(2005) Redes Globais de políticas públicas como coalizões para mudança. In: Esty, D.,\& Inavona, M.H.(eds.), Governança Ambiental Global:Opções e Oportunidades: São Paulo:Senac, p. 301.

Steurer, R., L.E.Markus., A.Konrad. , A.Martinuzz, 2005. Corporations, Stakeholders and Sustainable Development I:A Theoretical Exploration of Business-Society Relations. Journal of Business Ethics, 61, 263-281, Springer.

Thevenot, L.(1989). Economie et politique de l'entreprise: economies de l'eficicacite et de la confiance, In: Justesse et justice dans le travail. Paris, CEE-PUF.

Thévenot, L. (2001). Organized Complexity: Conventions of coordination and the composition of economic arrangements. European Journal of Social Theory. 2001.

Welp, M., \& Stoll-Kleemann, S.(2006). Integrative Theory of Reflexive Dialogues', in StollKleemann, S., \& Welp, M. (eds.), Stakeholder Dialogues in Natural Resources Management, Springer-Verlag, Heidelberg.

Welp, M., Vega-Leinert, A.C., Stoll-Kleeman, S., \& Furstenau, C.(2006a) Science-based Stakeholder Dialogues in Climate Change Research', In: Stoll-Kleemann.,\& S.,Welp, M (eds.), Stakeholders Dialogues in Natural Resources Management, Springer-Verlag, Heidelberg.

welp, M.; De La Vega-Leinert, A.,Stoll-Kleemann, S.,\& Jaeger, C. C.(2006b) Science-based stakeholder dialogues: Theories and tools. Global Environmental Change, 16(2),170.

Wilkinson, J. (1997).A new paradigm for economic analysis?. Economy and Society, 26(3).

Acknowledgment: The authors would like to thank CNPq (National Council for Scientific and Technological Development). 